\title{
Effects of Chromium (III) Picolinate and Chromium (III) Picolinate Nanoparticles Supplementation on Growth Performance, Organs Weight and Immune Function in Cyclic Heat Stressed Broiler Chickens
}

\author{
Omid HAMIDI ${ }^{1}$ Mohammad CHAMANI ${ }^{1}$ \& Hasan GHAHRI ${ }^{2}$ \\ Ali Asghar SADEGHI ${ }^{1}$ Hassan MALEKINEJAD ${ }^{3}$ \\ ${ }^{1}$ Department of Animal Sciences, Faculty of Agriculture and Natural Resources, Tehran Science and Research Branch, \\ Islamic Azad University, Tehran, IRAN \\ 2 Faculty of Veterinary Medicine, Urmia Branch, Islamic Azad University, Urmia, IRAN \\ ${ }^{3}$ Department of Pharmacology and Toxicology, Faculty of Veterinary Medicine, Urmia University, Urmia, IRAN
}

Article Code: KVFD-2015-14736 Received: 23.11.2015 Accepted: 25.02.2016 Published Online: 26.02.2016

\begin{abstract}
This experiment conducted to investigate the effects of dietary chromium (III) picolinate (CrPic) and chromium (III) picolinate nanoparticles (NanoCrPic) supplementation on growth performance, organs weight and immune function of broilers exposed to heat stress. Heat stress $\left(36^{\circ} \mathrm{C}\right)$ was applied for $10 \mathrm{~h}$ per day from the $21^{\text {th }}$ to the $42^{\text {nd }}$ days. Among 8 experimental treatments; only group T1 represented the non-heat stressed control group fed with a basal diet in comfort zone whereas group T2 represented the heat stressed control group fed with a basal diet. Heat stressed T3, T4, T5 groups were fed with basal diet supplemented with 500, 1.000, 1.500 ppb of CrPic/kg while T6, T7, T8 groups were fed with bsal diet supplemeted with 500,1.000, $1.500 \mathrm{ppb}$ of NanoCrPic/kg respectively. Results of the current experiment showed that the non-heat stressed group had a higher final BW, daily weight gain and daily feed intake compared with heat stressed groups during the experiment period (d 21-42), Among heat stressed groups, FCR values improved by supplementation of $\mathrm{Cr}$ into the diet. NanoCrPic 1.500 treatment had the lowest $(\mathrm{P}<0.05)$ FCR (2.14) of the total experimental period among heat stressed groups. The liver weight values of the day 35 of experiment differed significantly $(\mathrm{P}<0.05)$. Serum complement component $\mathrm{C} 3$ of experimental broilers was severely affected by the $\mathrm{Cr}$ supplementation. The results indicated that the nanoparticle supplementation might be an influential method for reduction of heat stress induced disorders which may attribute to the lowering of FCR and provoking the hepatic related alteration including the liver weigth.
\end{abstract}

Keywords: Chromium picolinate nanoparticles, Cyclic heat stress, Immune Function, Organs weight, Performance

\section{Krom (III) Pikolinat ve Krom (III) Pikolinat Nanopartikül Katkısının Siklik Isı Stresine Maruz Kalan Broiler Civcivlerde Büyüme Performansı, Organ Ağırlığı ve Bağışıklık Fonksiyonları Üzerine Etkileri}

\begin{abstract}
Özet
Bu çalışma krom (III) pikolinat (CrPic) ve krom (III) pikolinat nanopartikül (NanoCrPic) katkısının ısı stresine maruz kalan broiler civcivlerde büyüme performansı, organ ağırlığı ve bağışıklık fonksiyonları üzerine etkilerini araştırmak amacıyla yapıldı. Civcivlerde 21. ve 42. günler boyunca toplam 10 gün her gün uygulanmak suretiyle ısı stresi oluşturuldu. Toplam 8 grup oluşturuldu. T1 grubu hayvanlar Isı stresi uygulanmayan ve bazal diyet ile beslenen kontrol grubunu oluştururken T2 grubu hayvanlar bazal diyet alırken Isı stresine maruz bırakıldı. T3, T4 ve T5 gruplarındaki hayvanlar bazal diyet ile birlikte sırasıyla 500, 1000 ve 1500 ppb CrPic/kg; T6, T7 ve T8 gruplarındaki hayvanlar ise bazal diyet ile birlikte sırasıyla 500, 1.000 ve $1.500 \mathrm{ppb}$ NanoCrPic/kg katkısı aldılar. Çalışma sonucunda en yüksek nihai vücut ağırlığı, günlük ağırlık kazanımı ve günlük yem tüketimi ısı stresine maruz bırakılmayan hayvanlarda şekillendi. Isı stresi uygulanan gruplar arasında yem konversiyon oranı diyette $\mathrm{Cr}$ katkısı ile iyileşme gösterdi. NanoCrPic 1.500 uygulaması ısı stresi uygulanan gruplar arasında en düşük yem konversiyon oranına $(2.14)(P<0.05)$ neden oldu. Çalışmanın 35. günü sonunda karaciğer ağırlık değerleri anlamlı ölçüde farklııklar gösterdi $(P<0.05)$. Serum komplement bileşeni $C 3$ deneysel gruplarda şiddetli derecede Cr katkısı ile etkilenmişti. Çalışma sonucunda elde edilen bulgular doğrultusunda nanopartikül katkısı kullanımının ısı stresine bağlı olarak oluşan azaltmış yem konversiyon oranını düzeltme ve karaciğer ağırlık artışına katkıda bulunmada faydalı olacağı kanısına varıldı.
\end{abstract}

Anahtar sözcükler: Krom pikolinat nanopartikül, Siklik ısı stresi, Bağışıklık fonksiyonu, Organ ağırlığı, Performans

8 iletişim (Correspondence)

淈 +98912 3221336, Fax: +982144865484

m.chamani@srbiau.ac.ir 


\section{INTRODUCTION}

Heat stress (HS) is one of the most important commercial challenges that cause poor growth and has a negative influence on feed efficiency of broiler chickens. Broilers exposed to high environmental temperature display various behavioral and physiological disorders include feather pecking, tendency to inactivity, increase of body temperature, panting and respiratory alkalosis ${ }^{[1,2]}$. Briefly, HS is considered by decreased feed consumption, reduced metabolic rate, high mortality, reduced body weight gain, high feed conversion ratio, peroxidation of lipid, endocrine disorders, immunosuppression and intestinal microbial dysbiosis in poultry ${ }^{[3-6]}$. Also HS has been shown to decrease the total white blood cell count and antibody production ${ }^{[4]}$, reduction of the peripheral blood lymphocytes number, induction of an electrolyte imbalance ${ }^{[7]}$, decline spleen weight ${ }^{[8]}$ and diminution $\mathrm{CD}^{+} \mathrm{T}$ cells ( $\mathrm{T}$-helper lymphocytes) and $\mathrm{CD} 8^{+} \mathrm{T}$ cells (T-cytotoxic lymphocytes) ${ }^{[9]}$.

Some strategies for resolving this problem have been proposed to manage the negative effects of heat stress, including environmental management, nutritional manipulation as well as the addition of feed additives in the diet. Chromium-supplemented diets has shown to be effective in diminishing the negative effects of stress and improving immunity in broilers ${ }^{[10,11]}$. Chromium is an ingredient of glucose tolerance factor (GTF) and is essential for carbohydrate, fat, and protein metabolism likely by potentiating the action of insulin ${ }^{[12]}$. Stress and diseases lead to more urinary excretion of $\mathrm{Cr}$ and can cause exacerbating of marginal $\mathrm{Cr}$ deficiency ${ }^{[12]}$. Most poultry feedstuffs are mainly composed of plant source components, which are typically a low in contented of $\mathrm{Cr}^{[13]}$. It has been reported that the inclusion of CrPic in diet enhances daily gain, feed utilization and improve growth performance of broilers consumed low protein diets ${ }^{[14,15]}$. Chromium has been reported to have immunomodulatory properties ${ }^{[16-18]}$, which is assumed to be an indirect effect of chromium on the secretion of glucocorticoids, because corticosteroids have a depressing effect on the immune system ${ }^{[19,20]}$.

Recently, nanotechnology has rapidly been developing different scientific areas and nanoscale of materials has interested extention because nano-formulation particulates exhibit novel distinguishing quality such as a size, shape, large surface area, high surface activity, high catalytic efficiency and strong adsorbing ability [21]. Limited published data in various experimental conditions implicated higher absorption and bioavailability of chromium nanoparticles ${ }^{[22-24]}$. Previous researches have shown that chromium nanoparticles had beneficial properties on growth performance, body composition, as well as augmented tissue concentrations of $\mathrm{Cr}$ in selected muscles ${ }^{[25]}$ and serum ${ }^{[24]}$. Also and chromium nanoparticles can improve utilization of $\mathrm{Zn}, \mathrm{Fe}$ and $\mathrm{Ca}$ of broiler chickens ${ }^{[23]}$. Therefore, the purpose of this study was to investigate the effects of the supplementation of CrPic and NanoCrPic on performance, organs weight and immune function of broiler chickens exposed to cyclic heat stress $(10 \mathrm{~h} / \mathrm{d})$.

\section{MATERIAL and METHODS}

All experiments were carried out under the ethical guidelines of the Islamic Azad University of Tehran Science and Research Branch (93/987, in 2014).

\section{Birds and Grouping}

A total of 480 broiler chickens (Ross 308), from 21 to 42 days old (equal in both sex), were used in a completely randomized design. Chickens were purchased from a commercial hatchery and were housed in floor pens covered with sterilized and contaminant-free wood shavings with $10 \mathrm{birds} / \mathrm{m}^{2}$ and with water and food (hanging feeders) provided as ad libitum. The broiler chickens were observed for health status and behavior constantly. All chickens consumed a diet based on corn-soybean meal, which provided as mash form was formulated based on NRC 1996 by UFFDA software (Table 1). On day 21, the broiler chickens were weighed and, selected based on weight $(630 \pm 50 \mathrm{~g})$, re-allocated into 8 different groups: a control(thermoneutral) group and 7 independent heat-stressed groups and for each group of birds, 4 replications with 15 birds per box were made. Broilers in the control- (TN) and control+ (heat stress) groups were fed with no additive, whereas other groups were fed 500; 1.000; or $1.500 \mathrm{ppb}$ of CrPic, or 500; 1.000 or $1.500 \mathrm{ppb}$ of NanoCrPic, respectively. CrPic purchased from Sigma-Aldrich $\left[\left(\mathrm{C}_{18} \mathrm{H}_{12} \mathrm{CrN}_{3} \mathrm{O}_{6}\right)\right.$, Cat. no. $C 4124$, CAS Number $=14639-25-9$, USA] and Nanoparticles of chromium picolinate were prepared using the method that described by Lin et al..$^{[24]}$, briefly" mixture of dry ingredients contained of $10 \mathrm{~g}$ of chromium and $2.5 \mathrm{~g}$ of dispersed reagent silica was added to $240 \mathrm{ml}$ of $95 \%$ ethanol to make a semi-liquid mixture. The mixture was premixed for $1.5 \mathrm{~h}$ and then placed in a grind chamber with $500 \mathrm{~g}$ of $0.2 \mathrm{~mm}$ zirconium particles. The mixture was then ground for $1.5 \mathrm{~h}$ at $960 \mathrm{~g}$. After the grinding, the mixture was passed through a $0.074 \mathrm{~mm}$ (200 mesh) sieve to remove large particles. The mixture was then ovendried at $50^{\circ} \mathrm{C}$ overnight. The chromium nanoparticle powder was passed through a $0.074 \mathrm{~mm}$ sieve again" [24], finally the nanoparticles size was determined by a transmission electronic microscope (Philips Bio Twin 100 The Netherland) according to lin et al. ${ }^{[24]}$ and the average diameter of particles was $100 \mathrm{~nm}$ (Fig. 1).

The birds of control group (C) were kept comfort zone temperature $\left(23 \pm 1^{\circ} \mathrm{C}\right.$ from 21 to 28 day and $21 \pm 1^{\circ} \mathrm{C}$ from 28 42 day). The birds of heat-stressed groups were kept under $36 \pm 1^{\circ} \mathrm{C}$ ambient temperature from $08: 00$ to $18: 00 \mathrm{~h}=10 \mathrm{~h} / \mathrm{d}$ (from 21-42 day). From 18:00 to 08:00 $h$, the environmental temperature of the heat-stressed groups was reduced to the equal to that of the control- group. The birds in 42 days old were euthanized by cervical dislocation. 


\begin{tabular}{|c|c|c|c|c|c|c|c|c|c|}
\hline \multirow[b]{2}{*}{ Ingredients (\%) } & \multirow{2}{*}{$\begin{array}{l}\text { Starter } \\
(1-21 d)\end{array}$} & \multicolumn{8}{|c|}{ Finisher (21 - 42 d) } \\
\hline & & $\begin{array}{l}\text { Cont - } \\
\text { (T1) }\end{array}$ & $\begin{array}{c}\text { Cont }+ \\
\text { (T2) }\end{array}$ & $\begin{array}{c}\text { Cr500 } \\
\text { (T3) }\end{array}$ & $\begin{array}{l}\mathrm{Cr} 1000 \\
\text { (T4) }\end{array}$ & $\begin{array}{l}\text { Cr1500 } \\
\text { (T5) }\end{array}$ & $\begin{array}{l}\text { NCr500 } \\
\text { (T6) }\end{array}$ & $\begin{array}{l}\text { NCr1000 } \\
\text { (T7) }\end{array}$ & $\begin{array}{l}\mathrm{NCr} 1500 \\
\text { (T8) }\end{array}$ \\
\hline Corn & 60.7 & 66.0 & 66.0 & 66.0 & 66.0 & 66.0 & 66.0 & 66.0 & 66.0 \\
\hline Soybean meal & 30.0 & 24.0 & 24.0 & 24.0 & 24.0 & 24.0 & 24.0 & 24.0 & 24.0 \\
\hline Corn gluten meal & 2.5 & 3.0 & 3.0 & 3.0 & 3.0 & 3.0 & 3.0 & 3.0 & 3.0 \\
\hline Soybean oil & 2.3 & 2.55 & 2.55 & 2.55 & 2.55 & 2.55 & 2.55 & 2.55 & 2.55 \\
\hline Dicalcium phosphate & 1.7 & 1.7 & 1.7 & 1.7 & 1.7 & 1.7 & 1.7 & 1.7 & 1.7 \\
\hline Limestone & 1.2 & 1.2 & 1.2 & 1.2 & 1.2 & 1.2 & 1.2 & 1.2 & 1.2 \\
\hline Salt & 0.3 & 0.3 & 0.3 & 0.3 & 0.3 & 0.3 & 0.3 & 0.3 & 0.3 \\
\hline L-Lysin & 0.16 & 0.15 & 0.15 & 0.15 & 0.15 & 0.15 & 0.15 & 0.15 & 0.15 \\
\hline DL-Methionine & 0.14 & 0.10 & 0.10 & 0.10 & 0.10 & 0.10 & 0.10 & 0.10 & 0.10 \\
\hline Mineral and vitamin mix ${ }^{1}$ & 1.0 & 1.0 & 1.0 & 1.0 & 1.0 & 1.0 & 1.0 & 1.0 & 1.0 \\
\hline CrPic (ppb/kg) & - & - & - & 500 & 1000 & 1500 & - & - & - \\
\hline NanoCrPic (ppb/kg) & - & - & - & - & - & - & 500 & 1000 & 1500 \\
\hline $\begin{array}{l}\text { Calculated nutrient } \\
\text { composition }\end{array}$ & $\begin{array}{l}\text { Starter } \\
(1-21 d)\end{array}$ & \multicolumn{8}{|c|}{$\begin{array}{l}\text { Finisher } \\
\text { (21-42 d) }\end{array}$} \\
\hline $\mathrm{ME}(\mathrm{kcal} / \mathrm{kg})$ & 3120 & \multicolumn{8}{|c|}{3190} \\
\hline $\mathrm{CP}(\%)$ & 21.1 & \multicolumn{8}{|c|}{19.0} \\
\hline Lysine (\%) & 1.1 & \multicolumn{8}{|c|}{0.95} \\
\hline Methionine (\%) & 0.5 & \multicolumn{8}{|c|}{0.4} \\
\hline Calcium (\%) & 0.9 & \multicolumn{8}{|c|}{0.9} \\
\hline Total phosphorus (\%) & 0.4 & \multicolumn{8}{|c|}{0.4} \\
\hline \multicolumn{10}{|c|}{$\begin{array}{l}\text { 'Supplied per kilogram of diet: trans-retinyl acetate, } 25 \mathrm{mg} \text {; cholecalciferol, } 6 \mathrm{mg} \text {; menadione, } 1.2 \mathrm{mg} \text {; thiamine, } 2.3 \mathrm{mg} \text {; riboflavin, } 8 \mathrm{mg} \text {; nicotinamide, } 42 \\
\mathrm{mg} \text {; choline chloride, } 400 \mathrm{mg} \text {; calcium pantothenate, } 10 \mathrm{mg} \text {; pyridoxine } \mathrm{HCl}, 4 \mathrm{mg} \text {; biotin, } 0.04 \mathrm{mg} \text {; folic acid, } 1 \mathrm{mg} \text {; cobalamin, } 0.012 \mathrm{mg} \text {; Fe (from ferrous } \\
\text { sulfate), } 82 \mathrm{mg} \text {; Cu (from copper sulfate), } 7.5 \mathrm{mg} \text {; Mn (from manganese sulfate), } 110 \mathrm{mg} ; \mathrm{Zn} \text { (from zinc oxide), } 64 \mathrm{mg} \text {; (from calcium iodate), } 1.1 \mathrm{mg} \text {; Se (from } \\
\text { sodium selenite), } 0.28 \mathrm{mg}\end{array}$} \\
\hline
\end{tabular}

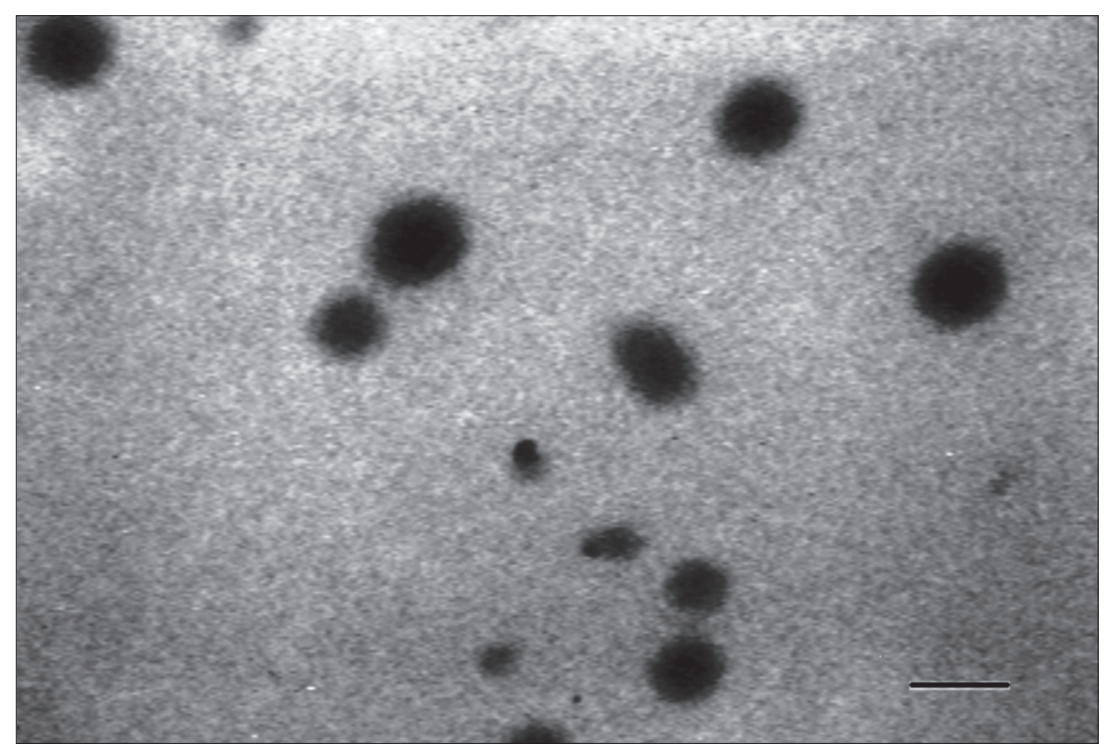

Fig 1. TEM image of nano-chromium (the average diameter was $100 \mathrm{~nm}$ )

Şekil 1. Nano-kromun TEM görüntüsü (ortalama çap $=100 \mathrm{~nm}$ )

\section{Vaccination}

All chickens were immunized intramuscularly with a killed vaccine of Newcastle virus at $8 d$ of age (Nobilis
ND LaSota, Intervet/Schering-Plough Animal Health, Boxmeer, the Netherlands). Live Newcastle disease vaccine was administered orally (drinking water) at 22 $\mathrm{d}$ of age. 


\section{Performance Parameters}

Broilers performance was assessed for mortality rate, BW gain, feed consumption per bird, and feed conversion. The feed conversion ratio was calculated on the basis of feed intake/gain for each replicate. Data were collected during the experimental period (ED21 to ED42).

\section{Organ Weights}

On ED28 and ED35 immediately after weighing, 8 birds per group ( 2 birds per pen) were randomly selected and euthanized by cervical dislocation. At necropsy, heart, liver and lymphoid organs (spleen, and bursa of Fabricius) were then picked up for relative weight determinations, \pm 0.01 $\mathrm{g}$ (connective tissue was removed before weighting).

\section{Plasma C3 and C4}

At the end of experiment period 8 birds per pen were randomly selected, and blood samples were collected from the wing vein. Blood samples were kept to at $4^{\circ} \mathrm{C}$ to coagulate, then samples centrifuged at $3.000 \times \mathrm{g}$ for $10 \mathrm{~min}\left(\right.$ at $4^{\circ} \mathrm{C}$ ) to separation of serum. Blood serum samples were stored at $-20^{\circ} \mathrm{C}$ until they were analyzed. Serum complement component 3 (C3), and complement component 4 (C4) concentrations were determined by commercial kits (Jiancheng Biological Engineering Research Institute, Nanjing, China, Cat. Nos. E032 and E033). The procedure was carried out according to the advised protocol of the company.

\section{Statistical Analysis}

All data were subjected to a one-way ANOVA procedure of SPSS 19.0 for Windows ${ }^{[26]}$, and the differences among means were separated by Duncan's multiple range test. A probability value of less than 0.05 was described to be statistically significant. Because there was no mortality during the experimental period so it has not been analyzed statistically.

\section{RESULTS}

\section{Performance Parameters}

The effects of different treatments on BW gain, feed intake and feed conversion ratio (FCR) throughout the experiment are presented in Table 2. The control group (TN group) had a higher final BW, daily weight gain and daily feed intake compared with heat stressed groups during

\begin{tabular}{|c|c|c|c|c|c|c|c|c|c|}
\hline \multirow{2}{*}{ Items } & \multicolumn{8}{|c|}{ Treatments } & \multirow{2}{*}{ SEM } \\
\hline & Control (-) & Control (+) & Cr500 & Cr1000 & Cr1500 & NCr500 & NCr1000 & NCr1500 & \\
\hline \multicolumn{10}{|l|}{$21-28 \mathrm{~d}\left(1^{\text {th }}\right.$ week $)$} \\
\hline Initial weight (day 21) $\left(\mathrm{kg} \mathrm{bird}^{-1}\right)$ & 0.593 & 0.661 & 0.591 & 0.621 & 0.619 & 0.625 & 0.638 & 0.615 & 0.0087 \\
\hline Final weight (day 28$)\left(\mathrm{kg} \mathrm{bird}^{-1}\right)$ & $0.874^{\mathrm{a}}$ & $0.872^{\mathrm{a}}$ & $0.837^{\mathrm{ab}}$ & $0.855^{\mathrm{ab}}$ & $0.832^{\mathrm{ab}}$ & $0.805^{b}$ & $0.822^{\mathrm{ab}}$ & $0.870^{\mathrm{a}}$ & $0.0063^{*}$ \\
\hline Daily feed intake $\left(\mathrm{kg} \mathrm{bird}^{-1}\right)$ & $0.068^{c}$ & $0.083^{\mathrm{a}}$ & $0.082^{\mathrm{a}}$ & $0.082^{\mathrm{a}}$ & $0.077^{\mathrm{ab}}$ & $0.072^{b c}$ & $0.081^{\mathrm{a}}$ & $0.080^{\mathrm{a}}$ & $0.0010^{* *}$ \\
\hline Daily weight gain $\left(\mathrm{kg} \mathrm{bird}^{-1}\right)$ & 0.040 & 0.032 & 0.031 & 0.036 & 0.033 & 0.035 & 0.035 & 0.035 & 0.0010 \\
\hline FCR & $1.72^{\mathrm{b}}$ & $2.62^{\mathrm{a}}$ & $2.66^{\mathrm{a}}$ & $2.28^{\mathrm{ab}}$ & $2.36^{\mathrm{ab}}$ & $2.07^{\mathrm{ab}}$ & $2.32^{\mathrm{ab}}$ & $2.29^{\mathrm{ab}}$ & $0.0951^{*}$ \\
\hline \multicolumn{10}{|l|}{$29-35 \mathrm{~d}\left(2^{\text {th }}\right.$ week $)$} \\
\hline Final weight $\left(\mathrm{kg} \mathrm{bird}^{-1}\right)$ & $1.595^{\mathrm{a}}$ & $1.367^{b}$ & $1.437^{b}$ & $1.350^{\mathrm{b}}$ & $1.354^{b}$ & $1.325^{b}$ & $1.392^{\mathrm{b}}$ & $1.374^{b}$ & $0.0196^{*}$ \\
\hline Daily feed intake $\left(\mathrm{kg} \mathrm{bird}^{-1}\right)$ & $0.154^{\mathrm{a}}$ & $0.154^{\mathrm{a}}$ & $0.155^{\mathrm{a}}$ & $0.149^{\mathrm{ab}}$ & $0.148^{\mathrm{ab}}$ & $0.140^{b}$ & $0.150^{\mathrm{ab}}$ & $0.148^{\mathrm{ab}}$ & $0.0011^{* *}$ \\
\hline Daily weight gain $\left(\mathrm{kg} \mathrm{bird}^{-1}\right)$ & $0.102^{\mathrm{a}}$ & $0.063^{c}$ & $0.092^{\mathrm{ab}}$ & $0.069^{b c}$ & $0.075^{\mathrm{bc}}$ & $0.066^{\mathrm{bc}}$ & $0.081^{b c}$ & $0.068^{\mathrm{bc}}$ & $0.0033^{* *}$ \\
\hline FCR & $1.51^{\mathrm{c}}$ & $2.44^{\mathrm{a}}$ & $1.68^{\mathrm{bc}}$ & $2.16^{\mathrm{ab}}$ & $1.97^{\mathrm{abc}}$ & $2.12^{\mathrm{abc}}$ & $1.85^{\mathrm{bc}}$ & $2.18^{\mathrm{ab}}$ & $0.0756^{*}$ \\
\hline \multicolumn{10}{|l|}{$36-42 \mathrm{~d}\left(3^{\text {th }}\right.$ week $)$} \\
\hline Daily feed intake $\left(\mathrm{kg} \mathrm{bird}^{-1}\right)$ & $0.221^{\mathrm{a}}$ & $0.167^{\mathrm{bc}}$ & $0.179^{b}$ & $0.162^{c}$ & $0.164^{c}$ & $0.165^{\mathrm{bc}}$ & $0.165^{b c}$ & $0.170^{\mathrm{bc}}$ & $0.0038^{* *}$ \\
\hline Daily weight gain $\left(\mathrm{kg} \mathrm{bird}^{-1}\right)$ & $0.082^{\mathrm{ab}}$ & $0.064^{\mathrm{ab}}$ & $0.071^{\mathrm{ab}}$ & $0.070^{\mathrm{ab}}$ & $0.070^{\mathrm{ab}}$ & $0.067^{\mathrm{ab}}$ & $0.059^{b}$ & $0.089^{\mathrm{a}}$ & $0.0025^{* *}$ \\
\hline FCR & $2.70^{\mathrm{a}}$ & $2.61^{\mathrm{a}}$ & $2.52^{\mathrm{ab}}$ & $2.31^{\mathrm{ab}}$ & $2.34^{\mathrm{ab}}$ & $2.46^{\mathrm{ab}}$ & $2.80^{\mathrm{a}}$ & $1.91^{\mathrm{b}}$ & $0.0735^{*}$ \\
\hline \multicolumn{10}{|l|}{$21-42 d$ (total) } \\
\hline Final weight ( $\left.\mathrm{kg} \mathrm{bird}^{-1}\right)$ & $2.176^{a}$ & $1.763^{c}$ & $1.986^{\mathrm{b}}$ & $1.769^{c}$ & $1.840^{\mathrm{bc}}$ & $1.730^{c}$ & $1.811^{\mathrm{c}}$ & $1.849^{\mathrm{bc}}$ & $0.0313^{*}$ \\
\hline Daily feed intake $\left(\mathrm{kg} \mathrm{bird}^{-1}\right)$ & $0.148^{\mathrm{a}}$ & $0.135^{\mathrm{bc}}$ & $0.139^{b}$ & $0.131^{\mathrm{cd}}$ & $0.130^{\text {cd }}$ & $0.126^{d}$ & $0.132^{\text {cd }}$ & $0.132^{c}$ & $0.0013^{* *}$ \\
\hline Daily weight gain $\left(\mathrm{kg} \mathrm{bird}^{-1}\right)$ & $0.075^{\mathrm{a}}$ & $0.053^{c}$ & $0.065^{b}$ & $0.058^{b c}$ & $0.059^{b c}$ & $0.056^{b c}$ & $0.058^{b c}$ & $0.064^{b}$ & $0.0015^{* *}$ \\
\hline FCR & $1.97^{b}$ & $2.55^{\mathrm{a}}$ & $2.14^{\mathrm{ab}}$ & $2.26^{\mathrm{ab}}$ & $2.20^{\mathrm{ab}}$ & $2.25^{\mathrm{ab}}$ & $2.28^{\mathrm{ab}}$ & $2.06^{b}$ & $0.0403^{* *}$ \\
\hline
\end{tabular}


the experiment period ( $d$ 21-42), whereas, all of these parameters improved significantly with the $\mathrm{Cr}$ inclusion to diet with different dosage and particle size. Moreover, the FCR value of control group (1.97) was found lower $(P<0.01)$ than that in heat- stressed groups and treatment NanoCrPic 1500 (2.06) had the lowest $(P<0.01)$ FCR value among heat stressed groups. Besides, as there was no mortality during the experimental period it has not been reported.

\section{Organ Weight}

The effect of different treatments on organs weight of broilers has been summarized in Table 3. Data belongs to two consecutive weeks of experiment ( $4^{\text {th }}$ to $5^{\text {th }}$ weeks). At the end of the $4^{\text {th }}$ week (one week after CrPic addition), there was a significant difference $(P<0.05)$ between the heart and bursa of Fabricius percentage among experimental treatments. Also, the spleen and liver weights were not affected significantly. As well, in the $5^{\text {th }}$ week of finishing period (d 35), NanoCrPic 500 (T6) had higher liver weight (3.75\% of live weight) in comparison with other treatments $(P<0.05)$.

\section{Immune Function}

The effects of CrPic and NanoCrPic supplementation on serum complement components in heat stressed broilers are shown in Table 4. The results indicated that, serum complement component C3 of experimental broilers was considerably affected by $\mathrm{Cr}$ addition. The concentrations of serum complement component $\mathrm{C} 3$ in the birds fed $1.500 \mathrm{ppb}$ NanoCrPic diet $(0.225 \mathrm{mg} / \mathrm{mL})$ were greater than birds fed chromium free or other levels of $\mathrm{Cr}$ and $\mathrm{NanoCr}$ diet from d 21 to $42(P<0.01)$. No significant differences were observed in serum complement component $\mathrm{C} 4$ concentrations among the control and test groups, although $\mathrm{C} 4$ values increased in some $\mathrm{CrPic}$ and NanoCrPic treatments but not significantly $(P>0.05)$.

\section{DISCUSSION}

Heat stress $\left(36^{\circ} \mathrm{C}\right)$, applied for $10 \mathrm{~h}$ per day from the $21^{\text {th }}$ to the $42^{\text {nd }}$ days of life decreased performance parameters in broilers in the present study. These data are in agreement with those reported elsewhere in similar contexts ${ }^{[5,6,27,28]}$. Chromium was reported to modulate feed intake of heat stressed chickens ${ }^{[27,29,30]}$, and our findings are corresponded with those documents. Also, the data showed that body weight $(P<0.05)$ and daily weight gain $(\mathrm{P}<0.01)$ improved with $\mathrm{Cr}$ addition significantly, and these are in agreement with ${ }^{[30]}$. Concerning to performance observations, it is well established that stress and disease exacerbate urinary excretion of $\mathrm{Cr}$ and this occurrence can worth a marginal $\mathrm{Cr}$ deficiency ${ }^{[12]}$. $\mathrm{Cr}$ is usually recognized

\begin{tabular}{|c|c|c|c|c|c|c|c|c|c|}
\hline \multirow{2}{*}{ Items } & \multicolumn{8}{|c|}{ Treatments } & \multirow{2}{*}{ SEM } \\
\hline & Contr - & Cont+ & Cr500 & Cr1000 & Cr1500 & NCr500 & NCr1000 & NCr1500 & \\
\hline \multicolumn{10}{|l|}{ Day 28 (\% live weight) } \\
\hline Heart & $0.59^{\mathrm{ab}}$ & $0.58^{\mathrm{abc}}$ & $0.46^{c}$ & $0.50^{\mathrm{bc}}$ & $0.56^{\mathrm{abc}}$ & $0.62^{\mathrm{a}}$ & $0.57^{\mathrm{abc}}$ & $0.52^{\mathrm{abc}}$ & 0.0149 \\
\hline Liver & 2.58 & 2.59 & 2.40 & 2.53 & 2.50 & 2.77 & 2.40 & 2.66 & 0.0510 \\
\hline Spleen & 0.08 & 0.10 & 0.10 & 0.09 & 0.10 & 0.07 & 0.10 & 0.07 & 0.0044 \\
\hline Bursa of Fabricius & $0.29^{\mathrm{a}}$ & $0.22^{\mathrm{ab}}$ & $0.23^{\mathrm{ab}}$ & $0.23^{\mathrm{ab}}$ & $0.22^{\mathrm{ab}}$ & $0.23^{\mathrm{ab}}$ & $0.29^{\mathrm{a}}$ & $0.24^{\mathrm{ab}}$ & 0.0110 \\
\hline \multicolumn{10}{|c|}{ Day 35 (\% live weight) } \\
\hline Heart & 0.58 & 0.54 & 0.46 & 0.51 & 0.53 & 0.54 & 0.49 & 0.47 & 0.0133 \\
\hline Liver & $2.66^{\mathrm{b}}$ & $2.65^{\mathrm{b}}$ & $3.10^{\mathrm{ab}}$ & $3.06^{\mathrm{ab}}$ & $2.64^{b}$ & $3.75^{\mathrm{a}}$ & $2.67^{\mathrm{b}}$ & $3.25^{\mathrm{ab}}$ & 0.0983 \\
\hline Spleen & 0.07 & 0.09 & 0.13 & 0.08 & 0.10 & 0.11 & 0.11 & 0.10 & 0.0067 \\
\hline Bursa of Fabricius & 0.21 & 0.18 & 0.22 & 0.19 & 0.21 & 0.18 & 0.17 & 0.19 & 0.0093 \\
\hline
\end{tabular}

Table 4. Effect of CrPic and NanoCrPic supplementation on serum complement components in heat stressed broilers

Tablo 4. Isı stresi uygulanan broiler civcivlerde CrPic ve NanoCrPic katkısı kullanımının serum komplement bileşenleri üzerine etkileri

\begin{tabular}{|c|c|c|c|c|c|c|c|c|c|}
\hline \multirow{2}{*}{ Items (mg/mL) } & \multicolumn{8}{|c|}{ Treatments } & \multirow{2}{*}{ SEM } \\
\hline & Cont - & Cont + & Cr500 & Cr1000 & Cr1500 & NCr500 & NCr1000 & NCr1500 & \\
\hline C3 & $0.197^{\mathrm{ab}}$ & $0.173^{b}$ & $0.174^{b}$ & $0.179^{b}$ & $0.181^{b}$ & $0.190^{\mathrm{ab}}$ & $0.194^{\mathrm{ab}}$ & $0.225^{\mathrm{a}}$ & $0.0042^{* *}$ \\
\hline C4 & 0.122 & 0.119 & 0.117 & 0.120 & 0.115 & 0.117 & 0.116 & 0.129 & 0.0029 \\
\hline
\end{tabular}


as the active component in the Glucose Tolerance Factor (GTF), which increases the sensitivity of tissue receptors to insulin and subsequent increase in glucose uptake by cells and finally increases oxidation of glucose. It was assumed that increased glucose uptake, reduced blood glucose and increased appetite should increase feed intake. Increased feed intake will tend to increase BW gain, because of improving amino acid and other nutrients consumption by tissues and muscle cells and increase protein retention which tends to increased body weight.

In the current study, the NanoCrPic administration resulted in influential effects on feed conversion ratio in the experimental period. It is theorized that when nutrients are digested, large particle size is degraded into small particle size, so they can be absorbed easily through the intestinal mucosa. In addition, the surface area of particles will increase and then enhance the digestion. Therefore, feed at nanoparticle scale may improve intestinal absorption. Some reports have indicated that nanoparticle drugs and minerals could increase absorption ${ }^{[31,32]}$. Lien et al. ${ }^{[33]}$ reported that as compared with regular $\mathrm{CrPic}$, the NanoCrPic significantly increased the CrPic digestibility in rats. According to the description, nanoparticles of chromium absorbed more and easier and made a strong impact.

Significant differences $(\mathrm{P}<0.05)$ were found in the heart, liver and lymphoid organs (Bursa of Fabricius and spleen) weight of heat stressed chickens treated with general sized $\mathrm{Cr}$ and Nano sized $\mathrm{Cr}$. The improvements in lymphoid organs are in agreement with Naghieh et al. ${ }^{[30]}$ and Moeini et al. ${ }^{[28]}$, although, others reported no significant effects of $\mathrm{Cr}$ supplementation on lymphoid organs weight ${ }^{[11,34]}$. In regards to, Bartlett and Smith ${ }^{[35]}$ suggest that the decrease in lymphoid organ weights might have been as a result of the reduction in feed consumption, so providing fewer nutrients for suitable growth of these organs under heat stress condition. Also, some findings showed that physiological stress is frequently associated with degeneration of lymphoid organs ${ }^{[36]}$ but the effects of $\mathrm{Cr}$ on these organs regeneration are not clear yet.

Serum complement component C3 increased significantly $(\mathrm{P}<0.01)$, with $\mathrm{CrPic}$ and NonoCrPic addition to diet of heat stressed broilers and there were lots of reports that indicate improving immune function with $\mathrm{Cr}$ inclusion ${ }^{[10,11,28,30,34]}$, and our findings are in agreement with those data. Also Serum complement component C4 increased in some treatments, especially in treatment NanoCrPic $1500(0.129 \mathrm{mg} / \mathrm{mL})$, but not significantly (P>0.05). Bahrami et al. ${ }^{[10]}$ and Toghyani et al. ${ }^{[34]}$ reported that serum lgG concentration increased in broiler chickens supplemented with $\mathrm{Cr}$ under heat-stress conditions. Moreover, Kegley and Spears ${ }^{[37]}$ observed that total IgG increased in feeder calves receiving supplemental chromium nicotinate under stress. In addition, Chang and Mowat ${ }^{[38]}$ and Moonsie-Shageer and Mowat ${ }^{[39]}$ reported that total IgG and IgM increased after transportation stress in calves supplemented with high-Cr yeast. To explain the improvement of immune function, heat stress induce a cascade of neural and hormonal events, beginning with hypothalamic stimulation and the production of corticotrophin-releasing factor, which stimulates the anterior pituitary to release $\mathrm{ACTH}$, and ending with stimulation of adrenal cortical tissue by ACTH to increase the production and release of corticosteroids (e.g. corticosterone and cortisol) primarily corticosterone, in birds ${ }^{[40]}$. Corticosterone prevents antibody production ${ }^{[41]}$. Zulkifli et al. ${ }^{[42]}$ reported that antibody production in young broiler chicks decreased in heat-stress conditions. This decline might be indirectly owing to an increase in inflammatory cytokines under stress, which stimulates the hypothalamic production of corticotrophin-releasing factor ${ }^{[43]}$. Chromium supplementation is detected to enhance the immune response, either through a direct effect on the cytokines ${ }^{[17]}$ or through the indirect effect of decreasing the glucocorticosteroid levels ${ }^{[19,20]}$. Myers et al. ${ }^{[4]]}$ observed that dietary chromium supplementation has an optimistic effect on the interleukin-6 levels in swine. The exact mechanism by which $\mathrm{Cr}$ improves the immune system is not known. However, a reliable result showed that $\mathrm{Cr}$ reduces serum cortisol levels. It is possibly not surprising that depletion in serum cortisol content is one of the principal mechanisms by which $\mathrm{Cr}$ alleviates heat stress-related depression in immunocompetent of broilers. Additionally, Sahin et al. ${ }^{[45]}$ found out that $\mathrm{Cr}$ supplementation improved serum insulin concentration while noticeably decreasing corticosterone concentration in laying hens at a low ambient temperature. This is a typical metabolic relation between insulin (anabolic) and corticosterone (catabolic), in which they have opposite effects on metabolism. A $\mathrm{Cr}$ deficiency can disrupt the metabolism of carbohydrates and protein and reduce insulin sensitivity in peripheral tissues ${ }^{[29,46]}$. Dietary $\mathrm{Cr}$ supplementation increased the plasma insulin concentration, indicating the physiological part of $\mathrm{Cr}$ in empowering the insulin to act as an insulin cofactor ${ }^{[45]}$.

Nanoparticles are of great scientific concern as they are effectively a bridge between bulk materials and atomic or molecular structures. With the knowledge of that the particle, when its dimension is reduced to nanometer size, exhibits new electrical, magnetic, mechanical and biological properties. Previouse reports have shown that nanoparticle drugs and minerals, possibly will increase absorption ${ }^{[31,32]}$. Lien et al. ${ }^{[33]}$ described that as compared with regular $\mathrm{CrPic}$, the NanoCrPic significantly increased the $\mathrm{CrPic}$ digestibility in rats. Furthermore, Wang and $\mathrm{Xu}$ (25) and Wang et al. ${ }^{[47]}$ reported that dietary supplementation with nanoparticle chromium increased the lean ratio, longissimus muscle area and tissue chromium content, while decreasing the fat ratio and back fat thickness in pigs. Zha et al. ${ }^{[22]}$ pointed out that Nano size chromium in the rat diet can significantly increase the average body weight gain, feed efficiency and lean mass weight, and 
reduce the body fat ratio and serum insulin concentration. Besides, numerous studies have shown that nanoparticles are more inclined to be recognized by the immune system and ingested by immune cells, such as macrophages, monocytes and leukocytes ${ }^{[48]}$. However, reports concerning nanoparticle chromium supplementation in broiler diets are rare, as only three published reports ${ }^{[23,24,49]}$ were found and there was not a considerable outstand marked study about using nanoparticles chromium in heat stressed broilers. Totally, although all of our findings were reaffirmation of chromium improve impact in heat stressed broilers, there were remarkable differences between normal and Nano sizes of $\mathrm{Cr}$ particles in this experiment that can be considered.

We tested the details of Chromium and Nanochromium effects on heat stressed broilers in this study. We concluded that chromium and chromium nanoparticles will be effective in heat stress situations, but the results indicated that nanoparticles may be more effective, although more research is needed to firm further.

\section{REFERENCES}

1. Harrison PC, Biellier HV: Physiological response of domestic fowl to abrupt changes of ambient air temperature. Poult Sci, 48, 1034-1045, 1969. DOI: $10.3382 /$ ps.0481034

2. Deyhim F, Teeter RG: Sodium and potassium chloride drinking water supplementation effects on acid-base balance and plasma corticosterone in broilers reared in thermoneutral and heat-distressed environments Poult Sci, 70, 2551-2553, 1991. DOI: 10.3382/ps. 0702551

3. Lan PT, Sakamoto M, Benno Y: Effects of two probiotic Lactobacillus strains on jejunal and cecal microbiota of broiler chicken under acute heat stress condition as revealed by molecular analysis of $16 \mathrm{~S}$ rRNA genes. Microbiol Immunol, 48, 917-929, 2004. DOI: 10.1111/j.1348-0421.2004. tb03620.x

4. Mashaly MM, Hendricks GL, Kalama MA, Gehad AE, Abbas AO, Patterson PH: Effect of heat stress on production parameters and immune responses of commercial laying hens. Poult Sci, 83, 889-894 2004. DOI: $10.1093 / \mathrm{ps} / 83.6 .889$

5. Sohail MU, ljaz A, Yousaf MS, Ashraf K, Zaneb H, Aleem M, Rehman H: Alleviation of cyclic heat stress in broilers by dietary supplementation of mannan-oligosaccharide and Lactobacillus-based probiotic: Dynamics of cortisol, thyroid hormones, cholesterol, C-reactive protein, and humoral immunity. Poult Sci, 89, 1934-1938, 2010. DOI: 10.3382/ps.2010-00751

6. Sohail MU, Rahman ZU, ljaz A, Yousaf MS, Ashraf K, Yaqub T, Zenab H, Anwar H, Rehman H: Single or combined effects of mannanoligosaccharides and probiotics supplements on the total oxidants, total antioxidants, enzymatic antioxidants, liver enzymes and serum trace minerals in cyclic heat stressed broilers. Poult Sci, 90, 2573-2577, 2011. DOI: 10.3382/ps.2011-01502

7. Borges SA, Fischer da Silva AV, Majorka A, Hooge DM, Cummings KR: Physiological responses of broiler chickens to heat stress and dietary electrolyte balance (sodium plus potassium minus chloride, milliequivalents per kilogram). Poult Sci, 83, 1551-1558, 2004. DOI: 10.1093/ps/83.9.1551

8. Trout JM, Mashaly MM: The effects of adrenocorticotropic hormone and heat stress on the distribution of lymphocyte populations in immature male chickens. Poult Sci, 73, 1694-1698, 1994. DOI: 10.3382/ps.0731694

9. Khajavi M, Rahimi S, Hassan ZM, Kamali MA, Mousavi T: Effect of feed restriction early in life on humoral and cellular immunity of two commercial broiler strains under heat stress conditions. Br Poult Sci, 44, 490-497, 2003. DOI: 10.1080/000071660310001598328
10. Bahrami A, Moeini MM, Ghazi SH, Targhibi MR: The effect of different levels of organic and inorganic chromium supplementation on immune function of broiler chicken under heat-stress conditions. J Appl Poult Res, 21, 209-215, 2012. DOI: 10.3382/japr.2010-00275

11. Ebrahimzadeh SK, Farhoomand P, Noori K: Immune response of broiler chickens fed diets supplemented with different level of chromium methionine under heat stress conditions. Asian-Aust J Anim Sci, 25, 256-260, 2012. DOI: 10.5713/ajas.2011.11217

12. Pechova A, Pavlata L: Chromium as an essential nutrient: A review. Veterinarni Medicina, 52 (1): 1-18, 2007.

13. Giri J, Usha KA, Sunita T: Evaluation of the selenium and chromium content of plant foods. Plant Foods Hum Nutr, 40, 4959, 1990. DOI: 10.1007/BF02193779

14. Kim S, Han WIK, Choi YJ, Kim YH, Shin IS, Chae BJ: Effect of chromium picolinate on growth performance, carcass composition, and serum traits of broilers fed dietary different levels of crude protein. Asian Australas J Anim Sci, 5, 463-470, 1995. DOI: 10.5713/ajas.1995.455

15. Khan RU, Naz S, Dhama K, Saminathan M, Tiwari R, Jeon GJ, Laudadio V, Tufarelli V: Modes of action and beneficial applications of chromium in poultry nutrition, production and health: A review. Int $\mathrm{J}$ Pharmacol, 10, 357-367, 2014. DOI: 10.3923/ijp.2014.357.367

16. Kegley EB, Spears JW, Brown TT: Effect of shipping and chromium supplementation on performance, immune response, and disease resistance of steers. J Anim Sci, 75, 1956-1964, 1997.

17. Borgs $\mathbf{P}$, Mallard BA: Immune-endocrine interactions in agricultural species: Chromium and its effect on health and performance. Domest Anim Endocrinol, 15, 431-438, 1998. DOI: 10.1016/S0739-7240(98)00018-6

18. Rajalekshmi M, Sugumar C, Chirakkal H, Ramarao SV: Influence of chromium propionate on the carcass characteristics and immune response of commercial broiler birds under normal rearing conditions. Poult Sci, 93, 574-580, 2014. DOI: 10.3382/ps.2013-03373

19. Mirfendereski E, Jahanian R: Effects of dietary organic chromium and vitamin $C$ supplementation on performance, immune responses, blood metabolites, and stress status of laying hens subjected to high stocking density. Poult Sci, 94, 281-288, 2015. DOI: 10.3382/ps/peu074

20. Samanta S, Haldar S, Ghosh TK: Production and carcass traits in broiler chickens given diets supplemented with inorganic trivalent chromium and an organic acid blend. Br Poult Sci, 49, 155-163, 2008. DOI: 10.1080/00071660801946950

21. Wijnhoven SW, Peijnenburg WJ, Herberts CA, Hagens WI, Oomen AG, Heugens EH, Roszek B, Bisschops J, Gosens I, Van De Meent D, Dekkers S: Nano-silver- A review of available data and knowledge gaps in human and environmental risk assessment. Nanotoxicology, 3, 109-138, 2009. DOI: $10.1080 / 17435390902725914$

22. Zha L, Zeng J, Sun S, Deng H, Luo H, Li W: Chromium (III) nanoparticles affect hormone and immune responses in heat-stressed rats. Biol Trace Elem Res, 129, 157-169, 2008. DOI: 10.1007/s12011-0088282-9

23. Sirirat N, Lu JJ, Hung Alex TY, Chen SY, Lien TF: Effects different levels of nanoparticles chromium picolinate supplementation on growth performance, mineral retention, and immune responses in broiler chickens. J Agri Sci, 4, 48-58, 2012. DOI: 10.5539/jas.v4n12p48

24. Lin YC, Huang JT, Li MZ, Cheng CY, Lien TF: Effects of supplemental nanoparticle trivalent chromium on the nutrient utilization, growth performance and serum traits of broilers. J Anim Physiol Anim Nutr, 99, 59_65, 2015. DOI: 10.1111/jpn.12215

25. Wang MQ, Xu ZR: Effect of chromium nano-particle on growth performance, carcass characteristics, pork quality and tissue chromium in finishing pigs. Asian-Aust J Anim Sci, 17, 1118-1122, 2004. DOI: 10.5713/ ajas.2004.1118

26. Wilkinson L: "Systat." Wiley Interdisciplinary Reviews: Comp Stat, 2, 256-257, 2010. DOI: 10.1002/wics.66

27. Toghyani M, Shivazad M, Gheisari AA, Zarkesh HS: Performance, carcass traits and hematological parameters of heat stressed broiler chicks in response to dietary levels of chromium picolinat. Int J Poult Sci, 5, 65-69, 2006. DOI: 10.3923/ijps.2006.65.69 
28. Moeini MM, Bahrami A, Ghazi S, Targhibi MR: The effect of different levels of organic and inorganic chromium supplementation on production performance, carcass traits and some blood parameters of broiler chicken under heat stress condition. Biol Trace Elem Res, 144, 715724, 2011. DOI: 10.1007/s12011-011-9116-8

29. Sahin K, Sahin N, Onderci M, Gursu F, Cikim G: Optimal dietary concentration of chromium for alleviating the effect of heat stress on growth, carcass qualities, and some serum metabolites of broiler chickens. Biol Trace Elem Res, 89, 53-64, 2002. DOI: 10.1385/BTER:89:1:53

30. Naghieh A, Toghyani M, Gheisari AA, Egbal Saeed S, Mirzazade $\mathrm{H}$ : Effect of different sources of chromium on performance and immune responses of broiler chicks. J Anim Vet Adv, 9, 354-358, 2010. DOI: 10.3923/ javaa.2010.354.358

31. Florence AT, Hillery AM, Hussain N, Jani PU: Nanoparticles as carriers for oral peptide absorption: Studies on particle uptake and fate. $J$ Control Release, 36, 39-46, 1995. DOI: 10.1016/0168-3659(95)00059-H

32. Desai MP, Labhasetwar V, Walter E, Levy RJ, Amidon GL: The mechanism of uptake of biodegradable microparticles in caco- 2 cell is size dependent. Pharm Res, 14, 1568-1573, 1997. DOI: 10.1023/A 1012126301290

33. Lien TF, Yeh HS, Lu FY, Fu CM: Nanoparticles of chromium picolinate enhance chromium digestibility and absorption. J Sci Food Agric, 89, 1164-1167, 2009. DOI: 10.1002/jsfa.3569

34. Toghyani M, Zarkesh S, Shivazad M, Gheisari A: Immune responses of broiler chicks fed chromium picolinate in heat stress condition. $J$ Poult Sci, 44, 330-334, 2007. DOI: 10.2141/jpsa.44.330

35. Bartlett JR, Smith MO: Effects of different levels of zinc on the performance and immunocompetence of broilers under heat stress. Poult Sci, 82, 1580-1588, 2003. DOI: 10.1093/ps/82.10.1580

36. Thaxton P, Siegel HS: Depression of secondary immunity by high environmental temperature. Poult Sci, 51, 1519-1526, 1972. DOI: 10.3382/ ps.0511519

37. Kegley EB, Spears JW: Immune response, glucose metabolism, and performance of stressed feeder calves fed inorganic or organic chromium. J Anim Sci, 73, 2721-2726, 1995.

38. Chang $X$, Mowat DN: Supplemental chromium for stressed and growing feeder calves. J Anim Sci, 70, 559-565, 1992.

39. Moonsie-Shageer S, Mowat DN: Effect of level of supplemental chromium on performance, serum constituents, and immune status of stressed feeder calves. J Anim Sci, 71, 232-238, 1993

40. Siegel HS: Stress, strains and resistance. Br Poult Sci, 36, 3-22, 1995. DOI: 10.1080/00071669508417748

41. Gross WB: Effect of short-term exposure of chickens to corticosterone on resistance to challenge exposure with Escherichia coli and antibody response to sheep erythrocytes. Am J Vet Res, 53 (3): 291-293, 1992.

42. Zulkifli I, Che Norma MT, Israf DA, Omar AR: The effect of early age feed restriction on subsequent response to high environmental temperatures in female broiler chickens. Poult Sci, 79, 1401-1407, 2000. DOI: $10.1093 / \mathrm{ps} / 79.10 .1401$

43. Ogle CK, Valente JF, Guo X, Li BG, Ogle JD, Alexander JW: Thermal injury induces the development of inflammatory macrophages from non-adherent bone marrow cells. Inflammation, 21, 569-582, 1997. DOI: 10.1023/A:1027377904641

44. Myers MJ, Farrell DE, Evock-Clover CM, Cpoe CV, Henderson M, Steel NC: Effect of recombinant growth hormone and chromium picolinate on cytokine production and growth performance in swine. Pathobiology, 63, 283-287, 1995. DOI: 10.1159/000163962

45. Sahin K, Küçük O, Sahin N: Effects of dietary chromium picolinate supplementation on performance, insulin and corticosterone in laying hens under low ambient temperature. J Anim Physiol Anim Nutr, 85, 142147, 2001. DOI: 10.1046/j.1439-0396.2001.00314.x

46. Sahin K, Sahin N, Küçük O: Effects of chromium, and ascorbic acid supplementation on growth, carcass traits, serum metabolites, and antioxidant status of broiler chickens reared at a high ambient temperature $\left(32^{\circ} \mathrm{C}\right)$. Nutr Res, $23,225238,2003$. DOI: $10.1016 / \mathrm{S} 0271-$ 5317(02)00513-4

47. Wang MQ, Xu ZR, Zha LY, Lindemann MD: Effects of chromium nanocomposite supplementation on blood metabolites, endocrine parameters and immune traits in finishing pigs. Anim Feed Sci Technol, 139, 69-80, 2007. DOI: 10.1016/j.anifeedsci.2006.12.004

48. Dobrovolskaia MA, Aggarwal P, Hall JB, McNeil SE: Preclinical studies to understand nanoparticle interaction with the immune system and its potential effects on nanoparticle biodistribution. Mol Pharmacol, 5, 487-495, 2008. DOI: 10.1021/mp800032f

49. Sirirat N, Lu JJ, Hung Alex TY, Lien TF: Effect of different levels of nanoparticles chromium picolinate supplementation on performance, egg quality, mineral retention, and tissues minerals accumulation in layer chickens. J Agri Sci, 5, 150-159, 2013. DOI: 10.5539/jas.v5n2p150 